\title{
E-book usage amongst academic librarians in South Africa
}

\author{
Sandy Zinn' and Natasha Langdown ${ }^{2}$ \\ Department of Library and Information Science, University of the Western Cape \\ szinn@uwc.ac.za; nlangdown@uwc.ac.za
}

Received 21 January 201 I
Accepted 22 July 201 I

\begin{abstract}
The purpose of this study completed in 2010 was to investigate the use of e-books amongst academic librarians; in particular which e-books are available to academic librarians, why they choose this format, what impact e-books have on librarians' professional practice and what the usage patterns of e-books are amongst academic librarians. A web-based questionnaire was distributed on the LIASA mailing list. The results reflect a more gradual trend towards e-book adoption. There is still a preference for print or a "bit of both" - print and electronic. This is because of the high costs of e-books using the subscription model as the predominant e-book acquisition model and the lack of sufficient e-books in all subject fields. E-books are used for "browsing for information" and are selected for functionalities such as having the ability to search the document, anytime access and automatic citation. Major problems identified with e-books are: the cost of the equipment to read e-book formats; the cost of the e-books, especially if the subscription purchasing model is used; the lack of reliability of the Internet; and the lack of training in the use of e-books.
\end{abstract}

Keywords: Electronic books, academic librarians, e-book usage, e-book publishing, South Africa

\section{Introduction}

The digital environment has led to the changes in the creation, storage, access and delivery of information. Librarians have had to learn new knowledge and skills in order to meet ever expanding user needs for new information services using Information Communication Technologies (ICTs) and e-resources. The work of academic librarians is increasingly varied as it expands to keep up with the flow of information. Academic librarians therefore may now use a variety of electronic sources for articles, including e-books. The importance of e-book collections continues to grow in the higher education environment.

Dowdy, Parente and Vesper (200I) noted that it is difficult to define e-books because the environment is constantly evolving. In the context of this study, e-books are defined as the electronic versions of books that are generally accessible via the Internet or the electronic version of traditional print books that can be read by using a personal computer or an ebook reader.

The electronic information usage of academic librarians is linked to librarians' ICT usage. According to Adekunle, Omoba and Tella (2007), who conducted a survey to study the attitudes of selected Nigerian librarians in Ibadan towards ICTs, for a librarian to make use of ICTs or new electronic sources: the attitude should be positive; and there should be no fears of ICT as this widens the digital divide.

As digital technology has gained greater status in teaching and learning activities, the needs, expectations, and relationships of all stakeholders (faculties, students, librarians, and administrators) have changed significantly. Avet (2006: 155-156) discusses the use of Internet search engines as a reference tool for librarians and claims that the contribution of library and information professionals to reference work has increased rather than the reverse as electronic information sources have proliferated.

New technologies, such as e-books, are dramatically increasing the accessibility of information, and librarians are adapting to the evolving needs of users that emerge from the adoption of these new technologies. The rationale for this study is based on the new developments of e-books and e-readers. This study set out to determine if academic librarians in South Africa have adapted to the new formats of information, such as e-books, which present both challenges and opportunities in promoting them to library patrons.

\section{Literature review}

As electronic access to information increasingly becomes attractive, media such as books are moving to digital formats. There are two main types of electronic books (e-books): those which are born digital - that is, materials which may have originated from a digital source (for example some electronic records) - and those which have been digitised, that is the

I. Sandy Zinn is a Lecturer in the Department of Library and Information Science at the University of the Western Cape in South Africa.

2. Natasha Langdown is a master's student in the Department of Library and Information Science at the University of the Western Cape in South Africa. 
process of creating digital files by scanning or converting analogue materials. There appears to be very little research conducted on librarians' ability to implement the technology in South Africa. Most of the international research that focuses on librarians as users of technology investigates the librarians' attitudes toward technology in general (Stover 2000:39).

\subsection{Electronic books}

There are two main components to e-books: I) the hardware-devices called readers (desktop, laptop, hand-held PDA); and 2) the software - the software program that displays books on screens. The delivery of e-books through a CD-ROM format and the Internet are the most popular modes. In 1998 dedicated readers or hand-held devices were launched to the public (Siracusa 2009). Some of the more popular readers are the Sony Reader, iPad, HTC Flyer, Galaxy Tab, Motorola Xoom and the Kindle.

"The reader has evolved and become multifunctional" (Woll and Nathan 2006:286). We can see this with the Kindle 2 and Kindle DX as users can now do wireless transfer from the Amazon Kindle store and RSS feeds for blogs, with an experimental web browser and the ability to support multiple formats and enable such possibilities as listening to audiobooks on the Kindle (Amazon.com 2008 \& 2009).

\subsection{Benefits of e-books}

E-books help to move the library into the new century of digital Library 2.0 and virtual library capability, cheaper; space saving, offers 24/7 access and availability, remote access, full-text search capability, as well as copying and pasting. One of the main advantages of the e-book is that it is mobile. In this social networking age with websites like Shelfari, Library Shelf and applications on Facebook, users are able to chat and transfer their preferences for certain books. Other conveniences include being able to electronically bookmark a page, highlight passages, adjust text size and use different multimedia effects, such as "oral reading, animations, music and sound effects" (Korat \& Shamir 2007:248; Pavlik 2008:220).

\subsection{Disadvantages of e-books}

Despite the many advantages of e-books, there are deficiencies and vulnerabilities. The drawbacks are electronic equipment, lack of internet reliability, fragmented reading, compatibility of software, and the initial cost. Other disadvantages are navigation implications on an e-book device and unreliable life span in terms of long term digital storage (Bennett \& Landoni 2005: 10). The concept of a first edition is lost as one digital copy cannot be visually different from the next (Wikipedia Contributors 2009). When the electricity is out or the battery runs flat, you cannot read an e-book. If a certain format is discontinued, you may not be able to acquire new titles, especially if your reader is locked into that format. However, a change of software can sometimes fix the problem. It is usually extremely difficult to purchase electronic books without a credit card or PayPal account. Most handheld reading devices still cost too much for the average South African, but a desktop computer, laptop, or net book can be used.

Owning an e-book does not have the same permanence as owning a printed book. Books ordered through Amazon.com, for example, can only be loaded onto one device, e.g. a Kindle. Despite the fact that you have bought the book, it cannot be loaned to a friend by having it downloaded onto his/her Kindle or desktop. This also applies to certain e-book access agreements in libraries where the number of persons that are simultaneously allowed access is restricted and in some cases only a percentage of information may be downloaded on that person's computer. Access to the source therefore always remains online. Amazon can also at any stage decide to discontinue the access to a book if they break ties with the publisher or the author.

\subsection{E-book acquisition}

Amongst the largest vendors and publishers of e-books are NetLibrary, EBSCO, Ebrary, eBook Corp (EBL), Knovel, Swets, Ovid, O'Reilly/Safari, Books 24x7, and Thomson Gale (Silberer \& Bass 2007:24). The pricing and access models vary. E-books are available for purchase or subscription. In the last 3 years there has been a significant increase in publishers and vendors having e-book options which within the last year has developed into the cornerstone of the eresources and is essential in the migration of print to electronic media for virtual libraries.

In the subscription model an annual fee is paid to the vendor in order to have access for 12 months to the selected contents or subjects. Chan and Lai (2005:205,2 10) report on an e-book study at the University of Hong Kong Libraries (HKUL) which examines their e-book purchasing model. Based on the study they determine that the subscription model of e-books is highly unfavourable due to the cost difference of the ever increasing subscriptions and outright ownership of the journals.

An Ebrary (McKiel 2007) survey alludes to the fact that the preferred acquisition model is almost tied between the purchasing model (59\%) and subscription model (55\%). The preferences can be translated into a choice for content (purchase model) or quantity (subscription model). A majority of the respondents on the Ebrary survey note that they 
prefer not to duplicate the purchasing of print and electronic titles, although the status quo remains that most libraries purchase both electronic and print titles for their collection. Note has to be taken that although these librarians order duplications, according to the Ebrary survey, they only purchase these duplicates if usage is high (McKiel 2007:5).

\subsection{Academic librarians and e-books}

As e-books become increasingly popular in today's modern library, librarians are discovering new challenges in finding the best ways to acquire, catalogue, access and read information. Engel and Robbins (2008: 105-106, 1 I4) discuss the evolving roles for electronic resource librarians, part of which include teaching not just patrons but also librarians themselves how to use new e-resources.

In 2005, the University of Denver's Penrose Library conducted a survey of its users to determine their degree of knowledge of electronic books, how and why they use them, and their level of satisfaction with the format. As e-books gain a footing in academic research, librarians need to know not only which e-books users read, but why and how they read them. Based upon the usage statistics, the e-books are relatively well used and most respondents indicate a preference for print although a larger number of respondents benefit from the flexibility of using both (Levine-Clark 2006:285,29I,297-298).

Hardesty and Sugarman (2007:196-198, 203) suggest that to be knowledgeable about the latest trends is critical for the success of academic librarians. Their survey acknowledges that the librarians using new methods have created a "new librarian", one who is technologically advanced and keeps up to date with these technologies via Web 2.0 tools such as blogs and webcasts. However, their survey reveals that, as with e-books, the use of blogs and RSS feeds to keep up to date were least popular with the survey takers at the time of the survey.

Blynko (2007:22) reports in her survey that over $81 \%$ of responding librarians worldwide believed integrating electronic resources into their collections to be "very important". Ball (2009:22) suggests that e-books have become very important in the academic sphere and are part of a "professional media mix". The last few years has seen books, journals and databases converge into a major electronic medium. Academic librarians who know and use e-books see them as useful tools. The desire for users to use e-publications has grown exponentially with computer usage. The academic library has been inundated with opportunities to create collections of e-book materials for their users.

According to Silipigni-Connaway and Wicht (2007), user studies have shown that the academic community at large wants full text content and that they can easily get this information via the World Wide Web. In the Ebrary survey, the overall usage of e-books was good but usage inhibitors were lack of awareness, difficulty in reading and especially lack of training (McKiel 2007). The 2007 Global Librarian E-book Survey, conducted to better understand e-book usage, purchase drivers and inhibiting factors as well as digitisation and distribution needs of libraries, was completed by 583 respondents in 552 institutions, 48\% of which were non United States (McKiel 2007).

In a cost-benefit study it has been determined that library policy is a key factor in the implementation of e-books within academic libraries (Renner 2007). In this study librarians acknowledged that e-books were an opportunity to increase existing collections and enhance user's research experiences. Although the study acknowledges this, it says that e-books are still a developing market. The introduction of e-journals into collections has laid the foundation for developing better usage amongst users for e-books as they have already become use to this technology (Renner 2007).

According to the Joint Information Systems Committee's (JISC 2008) National e-Books Observatory Project conducted in the United Kingdom (UK) in 2007, the academic population was using online books for their scholarly work. The UK National E-Books Observatory study looks more deeply into this dimension of e-book use, asking survey respondents about their e-book reading behaviour. Woodward and Edward ( $200 \mathrm{la} \& 200 \mathrm{lb}$ ) outline the work of the UK JISC in the area of e-books. They further discuss how in an Ebrary survey librarians were asked why they had not bought more e-books, and the top answers were: "prices were too high; little from which to select; and better e-book access models are required". Ultimately they discuss what librarians really want from an e-book. According to the JISC E-book working group (CHEMS 2006), a report on the feasibility study of the acquisition of e-books by Higher Education (HE) libraries and the role of JISC, they essentially want current titles, multiple user access, easier access, a more systematic way of searching for e-books and finally the flexibility of choice between subscription and outright buying options.

Veldsman (2008) describes the attitude towards e-books as requiring a paradigm shift from scepticism to acceptance. Importantly, she talks about e-books for use rather than reading. In her view e-books are a resource for professionals and academics who use the information to produce research. In her opinion librarians only provide the information.

A Springer survey (2009) on the end user perspective asks the question why librarians are so quick to adopt e-books. The results indicate that the librarians believe that e-books enhance user access and book functionality while providing superior access to more content. The survey finds that the librarians value the space saving capabilities and the greater security of using electronic resources which reduce book losses and damage. They also discuss how e-books have begun 
to be "engaged in horizontal information seeking and power browsing" in other words users bounce from one resource to another skimming the material in order to gain the research they require (Springer 2009).

The findings of the Springer survey on the usage of e-books are consistent with the JISC study in the UK, which discovered that $60 \%$ of users surveyed had made use of e-books. The impact of e-books on libraries and librarians has created many opportunities and challenges. The opportunity for usage of e-books would be the full text access combined with searching capabilities. With the onset of e-readers the ability to access these "books" from anywhere and to have quick and easy access to new and updated revisions of textbooks and other necessary reading is inevitable (Chakrabarti \& Gurey 2009:419; Springer 2009).

The Consortium of Academic and Research Libraries of Illinois (CARLI) e-book survey was conducted in March 2009 to better understand the members' needs, management of the resource and plans for the near future. From this survey they were able to deduce that libraries expect a variety of features such as integrated links to Google Scholar, RSS feeds and the ability for federated searching. The conclusions noted from the survey were that the digital rights management limitations are unacceptable and the main finding was that the librarians as a whole are satisfied with the usage and the contents of the e-books (Consortium of Academic and Research Libraries of Illinois 2009).

Most studies today are comparisons in the virtual "fight" between e-books and print books, the differences, advantages, uses, and disadvantages of both sides (Sprague \& Hunter, 2008: I5I-I52). The focus for the current study is of librarians as users of the e-book.

\section{Research questions}

New ICTs are being introduced into the academic environment on an increasingly regular basis. Whilst previous research focused more broadly on the use of search engines and faculty usage of electronic databases, this specific investigation of librarians' knowledge and use of e-books provides new insights into academic librarian e-book usage. The research question addressed in this study is: to what extent are e-books being used among academic librarians in their work environment? The sub-problems derived from the research question are:

- Which e-books are available to academic librarians in the workplace?

- What are the usage patterns of e-books among academic librarians in the workplace?

- Why do academic librarians choose this format?

- What impact do the e-books have on librarians' professional practice?

\section{Methodology}

A survey questionnaire was distributed on the Library and Information Association of South Africa (LIASA) mailing list. The questionnaire included closed-ended, partially closed and open-ended questions. The librarians at South African universities' and research councils' libraries, who all subscribe to the LIASA mailing list, formed the sample for the study. Academic librarians at university and research council libraries provide an information service covering all formats, including e-books. They also make extensive use of databases and electronic information sources in answering reference queries.

\section{Findings and discussion}

The questionnaire findings are presented, discussed and interpreted to show the user behaviour of academic librarians in relation to e-books. The questionnaire distributed over the LIASA mailing list attracted 25 responses from a variety of institutions. The questionnaire had three main headings: Section A focuses on personal and job related information of the respondents - age, gender, qualifications, job title, computer and internet skills, etc.; Section B focuses on e-book information - for example, definitions, advantages, disadvantages, and usage; and Section $C$ examines e-book purchasing - for example, purchasing models and e-book budgets.

\subsection{Respondents' personal and job-related information}

Survey respondents are $88 \%$ female and $12 \%$ male. Librarianship has been a female-dominated industry for a number of years (Piper \& Collamer 200I:406). This phenomenon is depicted in the female to male ratio in the survey. The highest return rate came from librarians aged $50-59$ years. Lenzini $(2002: 88,89)$ calls librarianship the "greying profession" as most of the librarians are of the "baby boomer" era, namely between the ages of 40-59. Figure I shows that the majority of respondents have either an LIS Honours degree (36\%) or an LIS Masters degree (24\%). Twenty eight percent have a postgraduate professional LIS degree. By cross-tabulation it is evident that respondents in the 50-59 year age group have higher qualifications than younger age groups.

SA Jnl Libs \& Info Sci 20I I, 77(2) 


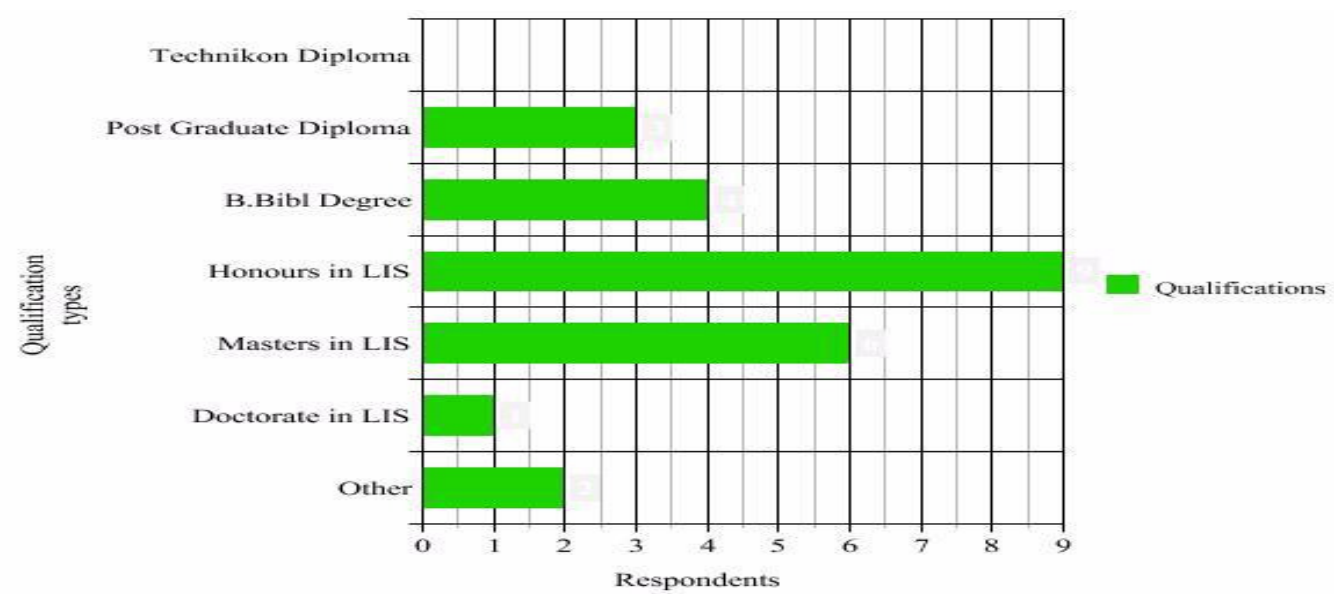

Figure 1 Qualifications

At least six (24\%) respondents refer to their job titles as "Head of Library and Information Services or Manager", while the rest call themselves some type of librarian (systems, cataloguing, information, senior). A large number of respondents seem to be in the management areas of their institutions and therefore the main decision makers. Towards the end of the $20^{\text {th }}$ century, the term librarian developed into a variety of different job titles such as Information Specialist, Systems Librarian and Meta Data Specialist.

The rate of return is $48 \%$ from historically advantaged universities, $20 \%$ from universities of technology, $12 \%$ from historically disadvantaged universities, $12 \%$ from research institutes or councils and $8 \%$ chose other (one respondent was from a "merged" university and another a private university). The majority of the 50-59 year old respondents come from historically advantaged institutions.

The highest response rates come from arts and humanities, although the respondents' fields of expertise are wideranging and include science and technology, medicine and health, social sciences, law, engineering, and business economics. The arts and humanities face difficulties in finding conventional publishers and may benefit from electronic publications. The transformation of old text has been made accessible via e-publication through established resources such as JSTOR and Google (Heath, Jubb \& Robey 2008).

A majority of respondents feel that their Internet search and computer literacy skills are very good to excellent. This result correlates positively with the high educational expertise of the majority of respondents who have many years of experience and training in using technology. Librarians in the $21^{\text {st }}$ century need to be able to find information across databases and the internet. The move from print to electronic journals, databases and e-books has witnessed a major shift in the importance of e-collections as an indicator of support for research (Brown \& Swan 2007).

\subsection{E-book Information}

There was a need to identify whether the respondents know about e-books and how and why they use them. These questions ranged from defining e-books to time spent reading and the advantages and disadvantages of e-books. The many detailed responses show that the respondents know what an e-book is. They provide various sound definitions of an e-book such as "digital copies of a book" and "a book which is available on the internet or database." The respondents all have a similar definition of an e-book corresponding with the literature.

The majority of respondents $(64 \%)$ claim to be either familiar or very familiar with e-books. Although two respondents indicated that they have not used e-books, not one respondent claims unfamiliarity with their library's ebooks. According to Wathen and Burkekk (2002: 137), users prefer print and look for the web equivalent which they find in e-books. Respondents in the survey who are familiar with their library's e-books are more likely to read electronic books or buy them.

Respondents were asked about the length of time spent reading e-books (see Figure 2) and a separate question asked how much of an e-book they read (see Figure 3). The results in Figure 2 are linked to the results in Figure 3: The time spent on e-books could be associated with how much content is actually read; and respondents read e-books in two specific ways - they either "dip in and out of several chapters" or they "skim read the text".

SA JnI Libs \& Info Sci 20II, 77(I) 
Figure 2 shows the majority read "less than a half an hour". This can be because the respondents assist students and researchers in obtaining information and guide users in the right direction. Veldsman (2008) believes that e-books are not aimed at librarians as librarians are but the conduits of information to the academic researchers. An alternative explanation is that users do not necessarily want to read at length on the computer (Rogers 2006: 25-26).

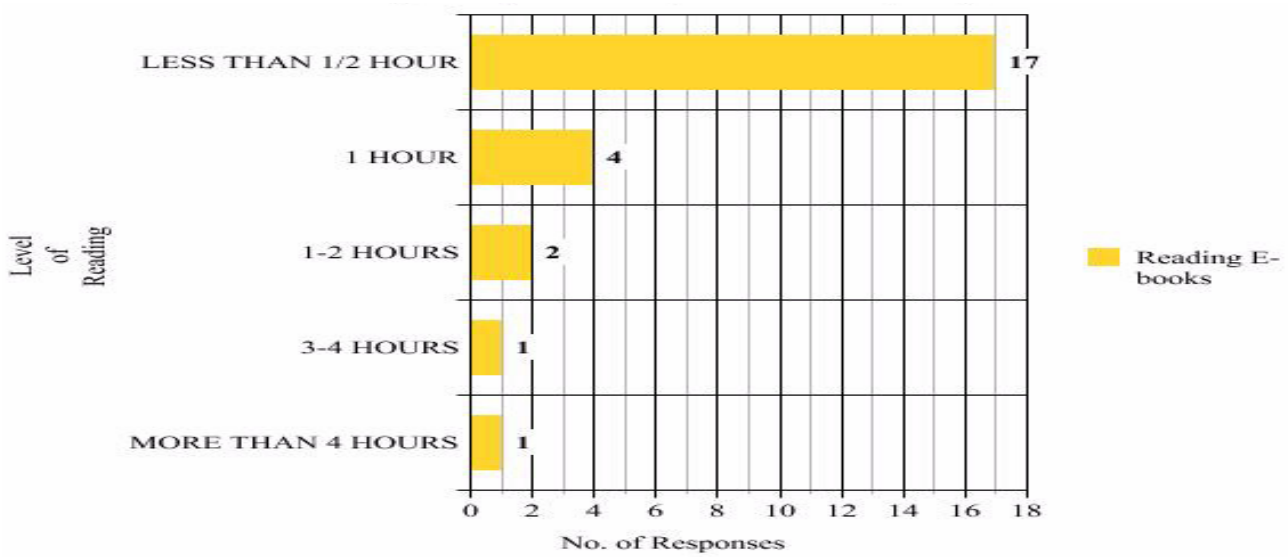

Figure 2 Length of time spent on e-books. $(\mathrm{N}=25)$

Figure 3 illustrates that $14(56 \%)$ academic librarians surveyed read an e-book by dipping in and out of several chapters and 8 (32\%) skim read. CIBER (2008:19) determined that this type of reading comes from a "Google generation trait". According to Rowlands, et al., $(2008: 295,300,306)$ the time spent reading is very short which has developed into a new reading behaviour. They further emphasize that as information is nowadays born digital, it would appear that this behaviour has become the norm amongst all users.

Readers are now skimming, dipping in and out of text and reading abstracts instead of the whole articles. The JISC National E-books Observatory Project's (2008:17) findings on the screen reading behaviour of users suggest that users derive the most satisfaction from "brief information and rapid fact extraction". The study also suggests that users prefer to print material to read later on and for making notes, which implies that e-books are an accompaniment to print materials. The "skimming" and "dipping in and out" provide a plausible explanation for an earlier discussion on the time spent reading e-books, where a fair number of respondents (68\%) are reading more or less half an hour at a time.

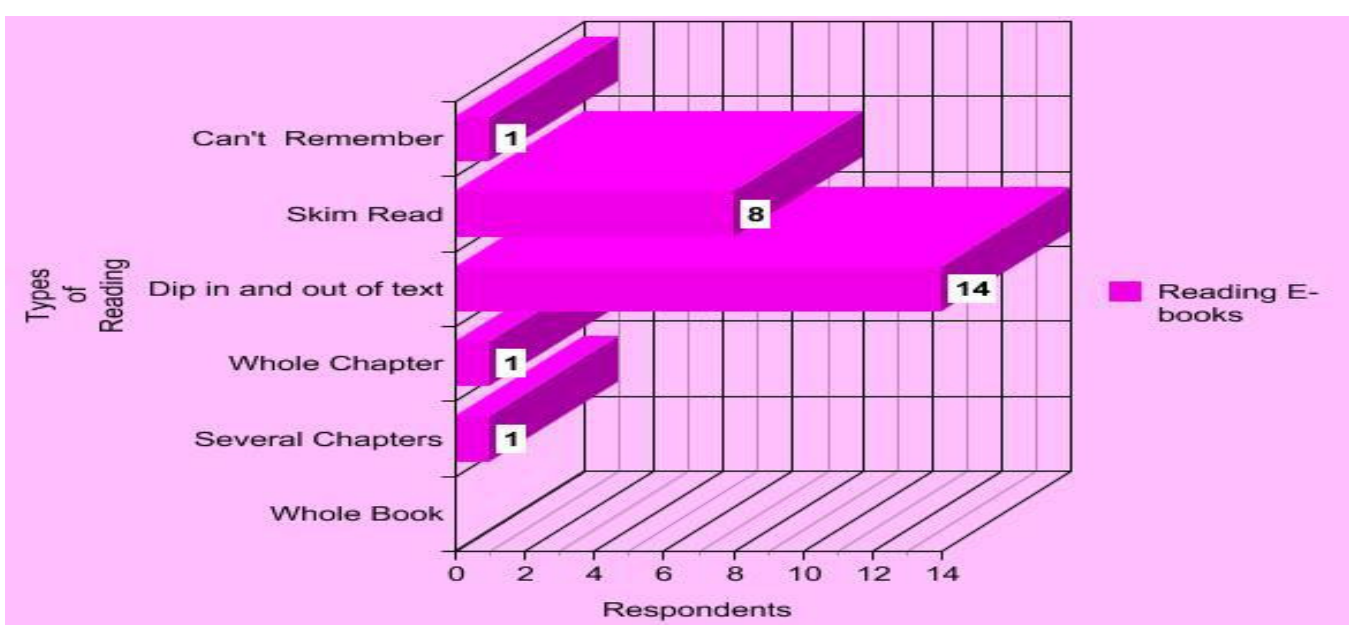

Figure 3 How much content is read $(\mathrm{N}=25)$ 
There are numerous advantages of e-books but the focus for this survey was on which advantages respondents determine to be the most relevant and important for their collections.

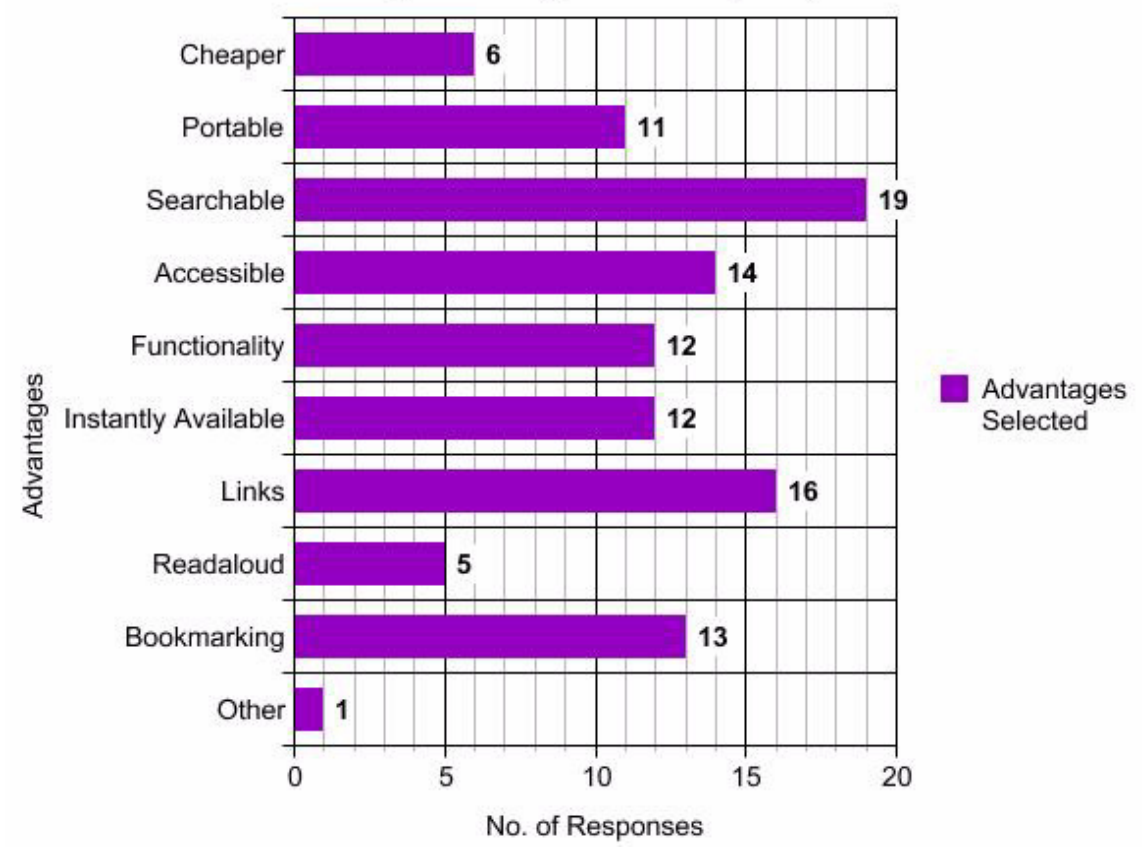

Figure 4 Advantages of e-books $(\mathrm{N}=25)$

Figure 4 indicates the searchability of e-books is most prized by respondents. In 2007, Ebrary conducted a Global Survey in which it wanted to determine the experience of university faculties with electronic resources and print materials. Of 333 responses, 164 cited the important advantages as ease of searching, finding, retrieving and distributing (Ebrary 2008a).

"Linking" is a surprising but understandable runner-up characteristic in this current study. A good example is the Ovid database from Wolters Kluwer where e-books are linked to e-journal articles and vice versa. Librarians value anytime accessibility, multiple users' access and searching and browsing capabilities because librarians are able to provide their patrons with more content with less shelf space. E-books help librarians connect to information that is needed without having to search the shelves or request searches or even inter-library loans.

The least selected "cheaper than print" option could be related to e-books purchase models, as often e-books are bought as part of collections rather than as individual titles. The responses to e-purchasing questions in the next section are telling. Some institutions are not purchasing e-books at all, for various reasons such as lack of computer access, faculty selection of e-books not taking place and with some of the institutions the budget also plays a role in the selection of ebooks and e-journals. As the majority of respondents purchase on a subscription basis, they can decrease or increase their selections each year to accommodate their budgets. E-publishing is discussed under the next heading.

What barriers to using e-books do respondents identify? Figure 5 below gives a breakdown of respondents' perceived drawbacks of e-books. It appears from the responses that librarians still prefer print to e-books. It also seems that the variety of e-books per subject is still limited. Cost as a disadvantage is rated highly and corresponds positively with the low rating respondents gave cost in the previous question. The Ebrary study (2008a, b) identified usability as a disadvantage. Usability is explained as difficulty in reading and lack of portability. In the current study the respondents' also prefer print. 


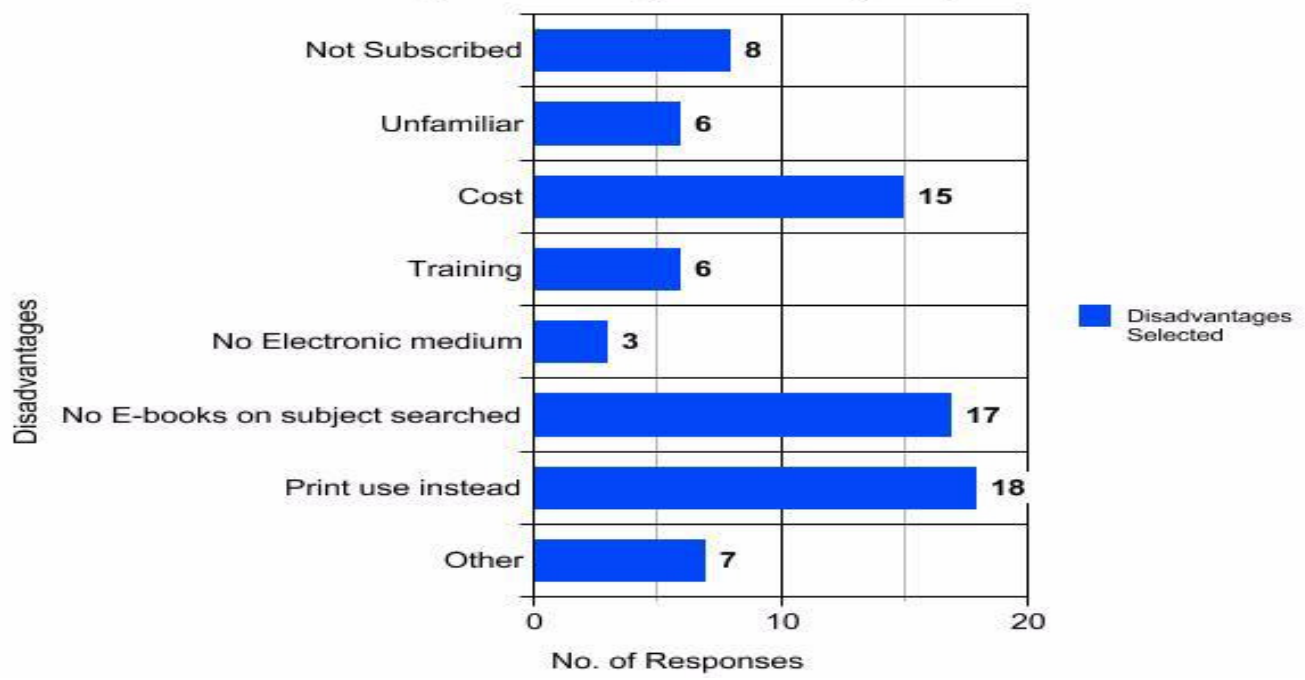

Figure 5 Disadvantages of e-books $(\mathrm{N}=25)$

In determining access routes to e-books, results show that the two most used methods are online databases and the Web, see Figure 6 below. Institutions subscribe to databases directly either via Ebrary, NetLibrary or Science Direct. Alternatively, e-books can be obtained via the Web (for example Google, online bookstores). Ebrary (2008b) determined from a survey of librarians from across the world that most chose, in this order, the "library catalogue"; "library website" and "Google". In the current study the "library catalogue" is ranked third. A reason could be that very few academic libraries in South Africa had federated searching facilities until the second half of 2010 . Twelve (48\%) respondents indicated that they access their information through subscriptions. This trend is contrary to overseas studies such as the University of Hong Kong Libraries study which determined that the subscription model of e-books was highly unfavourable due to the cost difference of the ever increasing subscriptions and outright ownership of the journals (Chan \& Lai 2005: 210).

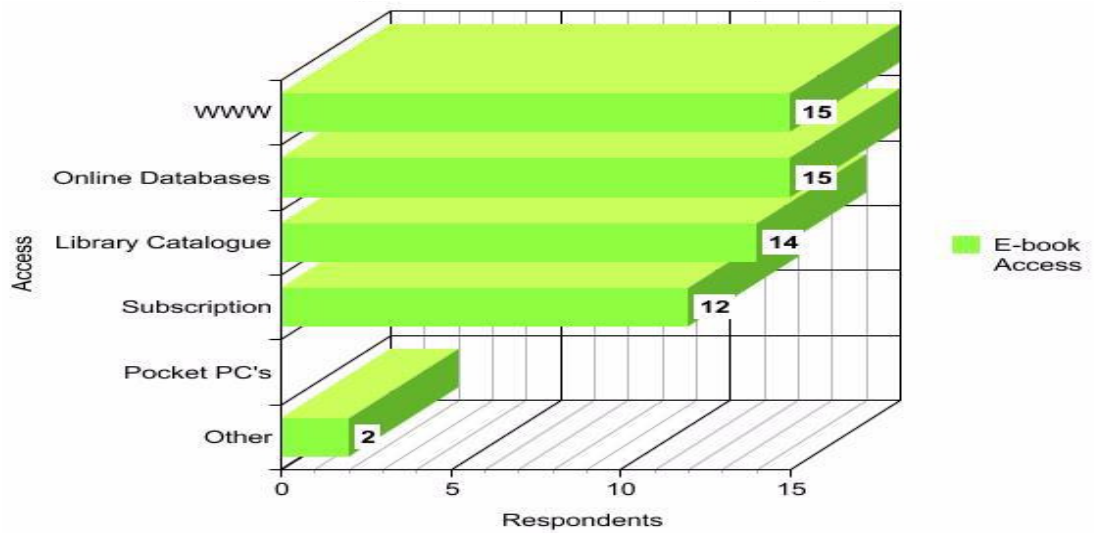

Figure 6 Access e-book information $(\mathrm{N}=25)$

The highest number of the respondents is reading content by printing out information as well as reading on the computer screen, referred to as "a bit of both". Rowlands, et al., (2007: 498) studied the preferences between reading electronically on the screen, reading from the printed page and "a bit of both" in different age groups. According to the study, the age groups between 46-55 and 56-64 years of age prefer reading "on the screen" and a "bit of both". This 
corresponds with the findings from the present survey where the majority of respondents are 50-59 years, and are more likely to do a "bit of both".

The preferred reading formats of respondents are hypertext markup language $(H T M L)$ and Portable Document Format (PDF). This finding corresponds well with the literature. According to Newman and Bui (2010:26) the main preference of e-book format usage is PDF. PDF can be used across campuses and easily transferred or uploaded onto an institution's Online Public Access Catalogue (OPAC).

The types of e-books the academic librarians use mostly are reference books and research monographs followed by directories. E-book readers such as the Kindle have only recently been introduced to South Africa. Perhaps one of the reasons for e-books being less associated with leisure-time reading is the PC or laptop dominant reading devices. The Anuradha and Usha (2006) study in India determined that e-reference books are mostly used within their institutions. What is surprising in their e-book study is that electronic monographs are used minimally because most institutions have larger collections of e-reference books than e-monographs.

According to McKiel (2007:4), the lack of training is a definite e-book usage inhibitor. Most of the participants in the current study consider training "very important" for finding and using e-books. Some library OPACs are sophisticated, making training a necessity. The most effective support and training tools for e-books chosen by $15(60 \%)$ respondents are in-person instruction and online tutorials by $14(56 \%)$ respondents. This is closely followed by online help pages selected by $12(48 \%)$ respondents. This suggests that, although participants enjoy learning on their own (online tutorials and online help), they still prefer human interaction. According to the Global Student E-book Survey's (Ebrary 2008b) I47 respondents from across the globe identify online tutorials and in-person instruction as the two most effective means of support, an outcome very similar to the present study.

\subsection{E-book purchasing}

During this austere economic period, libraries are faced with budget constraints which have increased in severity. Libraries as physical spaces continually experience difficulty in finding shelf space to accommodate growing print collections, making virtual libraries an attractive option. With the onset of e-book technologies and their integration with federated search engines, users and librarians alike are finding it easier to locate information online.

Eighteen institutions at the time of the current survey purchase e-books whilst seven do not. The purchase options vary for the eighteen. Some purchase by collections, agents, aggregators, or singularly. There are a variety of vendors around the world (Silberer \& Bass 2007:24) of which respondents selected Netlibrary, Ebrary, Books 24x7, Gale and Safari. E-book publishers mentioned by the respondents are: Blackwell Reference Online; Cambridge University Press, Elsevier; RSC Publishing; Taylor and Francis; SAGE; Springer; and Wiley InterScience Online Books. Amongst the e-book aggregators mentioned by the respondents are: Books@Ovid (from Ovid Technologies Inc.); Credo Reference; Dawsonera; Ebook Library (EBL); Ebrary; Gale Virtual Reference Library (from Gale/Cengage Learning); MyiLibrary (from Ingram Digital Group); Knovel; NetLibrary (from OCLC); Questia; Safari Books Online; Mdconsult; and Books24x7.

Those respondents whose institutions do not purchase e-books have problems such as no access to computers, budget constraints and non selection of e-books. These comments originate from across different institutions. The problems that these respondents mention can be linked to their previously expressed disadvantages of e-books. The Bennet and Landoni study (2005:14) highlight the main deficiencies and vulnerabilities as cost and electronic equipment too.

"Mobility" and "features" (such as audio, bookmarks, highlighting, etc) were the most selected reasons for buying ebooks. Responses here correlate well with their selections of the advantages of e-books. The literature also identifies ebooks' mobility and "features" as prime advantages. "Many e-books include different multimedia effects such as oral reading, animations, music and sound effects" (Korat \& Shamir 2007:248). E-books offer accessibility, flexibility, and searchability in ways print cannot - in addition to providing a fundamental means to knowledge discovery.

Which purchasing models do the institutions like best? The subscription model of purchasing was favoured by most respondents (14). The one time purchasing model was the second preferred selection model (8). The HKUL study (Chan \& Lai 2005) produced a different outcome. The subscription model of e-books was found to be highly unfavourable because of the cost difference between the ever increasing subscriptions and outright ownership of the journals (Chan \& Lai 2005:219). In the Ebrary (2007) survey about the preferred acquisition model, the purchase model performs only slightly better than the subscription model.

Four separate questions asked respondents about their dependency in the workplace on e-journals, free on-line ebooks, print and e-books respectively. Still reigning supreme in South African academic libraries is print, followed closely by e-journals. Purchased and free e-books come a distant third and fourth respectively. According to Levine-Clark 
(2006:287, 297-298) usage statistics indicate that e-books are relatively well used but most respondents indicate a preference for print although a larger number of respondents benefited from the flexibility of using both. E-journals score almost as highly as print material in the current survey indicating a faster adoption than with e-books. The current study indicates a more gradual shift in the usage of e-books. The world trend (in Ebrary 2008a \& b survey) points to over $50 \%$ of faculty opting for electronic resources, especially e-journals ( $88 \%$ ) and e-books $(65 \%)$. In the current study librarians are much more dependent on e-journals than e-books. A surprising $40 \%$ of respondents are still dependent on the CDROM format to access e-books in South Africa. CD-ROMs are used in libraries that are unable to access online databases through the Internet (Oduwole 2000:365). The unreliability of Internet access, especially in more rural areas, is a factor to consider.

In terms of the budget allocation, responses ranged from R0.00 (4 respondents) to between R50 000 and R300 000 (I respondent). Six respondents gauged their allocation at between RI and R4 million. Others indicated no actual figures but replied that their budget allocations were either unknown or not their responsibility (14). According to the librarians interviewed (in the Brown and Swan 2007 study) the natural trend towards e-book spending has reached II\% of their print spending and it was predicted that by the year $20 \mathrm{II}$ it will rise by $20 \%$.

\section{Conclusion}

The main thrust of this research was to investigate to what extent e-books are being used amongst academic librarians in their work environment in South Africa. The investigation focused on four main aspects: Firstly, which e-books are available to academic librarians in the workplace. Secondly, what the usage patterns of e-books are among academic librarians. Thirdly, the reasons the academic librarians choose this format and fourthly what the impact is of e-books on librarians' professional practice.

A variety of e-books are available to academic librarians. They access these e-books mainly via online databases, the Web and CD-ROM within institutions. The databases vary between different institutions according to budget constraints. The respondents indicated that aggregators and publishers such as Netlibrary, Ebrary, Blackwell, Elsevier and Safari are used in their institutions when sourcing documentation for their users. The main access difference between respondents in this study and respondents from the Ebrary (2008b) study is that respondents choose online databases first whilst theirs choose library catalogues.

Findings from this study indicate that academic librarians use e-books. Twelve respondents of the 18 whose institutions purchase e-books indicate that they would often or very often select e-books over print if the e-version is available.

Academic librarians choose to read e-books by "dipping in and out of several chapters" enabling them to read multiple documents at a time. Many readers have developed the "Google generation trait" where they read in shorter intervals and tend to skim read. The reading behaviour of librarians has been adjusted towards the ability to read on the internet. The diverse functionality of e-books enables the reader to apply habits formed from using the internet. Thus the preference for using either PDF or HTML format enables the user to apply these habits (bookmarking, searching, highlighting, linking and more) in order to find information within e-books.

Although many academic librarians are using e-books, constraints within some institutions determine that librarians are still using print mainly. When given a choice, $48 \%$ of respondents opted strongly for electronic over print media. Ebooks are being used in research, information referrals and reference queries. Here 12 (48\%) respondents are using ebook data more than $20 \%$ of the time in their referrals and reference queries. This study shows a gradual adoption of ebooks by academic librarians.

Libraries have the responsibility of providing quality information and resources for their clients. The problems associated with selecting e-books are (I) the cost of the equipment to read e-book formats; (2) the cost of the e-books especially if the subscription purchasing model is used; and (3) the reliability of the internet.

Veldsman (2008) describes the attitude towards e-books as a paradigm shift from skepticism to acceptance. This is evident as academic librarians have changed the way in which information is handled. According to the results of this study we find that e-books have impacted on, (I) reading behaviour; (2) purchasing behaviour; (3) Information use behaviour; and (4) collection development. Despite the limitations of e-book usage amongst academic librarians, they have accepted the resources as a vital part of their libraries. While frustration mounts with budget constraints in some institutions, we find that these academic librarians use free e-books available to add value to the institutions' electronic resources.

\section{References}

Adekunle, P.A., Omoba, R.O. \& Tella, A. 2007. Attitudes of librarians in selected Nigerian universities towards the use of ICT. Library Philosophy and Practice. [Online]. http://www.webpages.uidaho.edu/ mbolin/tella3.htm. (Accessed 9th April 2008). 
Amazon.com. 2008. Kindle user guide. Amazon.com. [Online]. http://g-ecx.images-amazon.com/images/G/0I/digital/fiona/general/ Kindle_User_Guide.pdf. (Accessed 23 March 2009).

Amazon.com. 2009 . Kindle DX user guide. Amazon.com. [Online]. http://s3.amazonaws.com/kindle/KindleDX_Users_Guide.pdf. (Accessed 20 June, 2009).

Anuradha, K.T. \& Usha, H.S. 2006. Use of e-books in an academic and research environment: A case study from the Indian institute of science. Program: Electronic Library and Information Systems, 40(I):48-62.

Avet, T. 2006. Who's afraid of Google? Library Journal, I3I(I0): I54-I56.

Ball, R. 2009. E-books in practice: the librarian's perspective. Learned Publishing, 22 (I): 18-22.

Bennett, L. \& Landoni, M. 2005. E-books in academic libraries. The Electronic Library, 23(I):9-16.

Blynko, B. 2007. Global survey offers insight into libraries' use of ebooks. Information Today, 24 (7):22.

Brown, S. \& Swan, A. 2007. Researchers' use of academic libraries and their services: a report commissioned by the research information network and the consortium of research libraries. London: Research Information Network. [Online]. http:// www.rin.ac.uk/files/libraries-report-2007.pdf. (Accessed 27 February 2008).

Centre for Information Behaviour and the Evaluation of Research (CIBER). 2008. Information behaviour of the researcher of the future. A CIBER briefing paper. London: CIBER. I-35. [Online]. http://www.bl.uk/news/pdf/googlegen.pdf. (Accessed 6 February 2009).

Chakrabarti, A. \& Gurey, P. 2009. The changing world of e-books. CALIBER 2009: e-Publishing. $7^{\text {th }}$ International CALIBER-2009. [Online]. http://www.inflibnet.ac.in/caliber2009/CaliberPDF/52.pdf. (Accessed 24 August 2009).

Chan, G.R.Y.C. \& Lai, J.K. 2005. Shaping the strategy for e-books: a Hong Kong perspective. Library Collections, Acquisition and Technical Services, 29 (2):205-219.

CHEMS - The Higher Education Consultancy Group. 2006. A feasibility study on the acquisition of e-books by HE libraries and the role of JISC. Final report. [Online]. http://www.jisc.ac.uk/media/documents/jisc_collections/ebooks\%20final\%20report \%205\%20oct.doc. (Accessed 18 May 2009).

CIBER. See Centre for Information Behaviour and the Evaluation of Research. Consortium of Academic and Research Libraries of Illinois (CARLI). 2009. CARLI e-book survey - executive summary. [Online]. http://www.carli.illinois.edu/comms/erwg/ E BookSurveyExecSummary.pdf. (Accessed 24 August 2009).

Dowdy, J., Parente, S. \& Vesper, V. 200I. E-books in the academy library. proceedings in the annual mid-semester instructional technology conference. [Online]. http://www.mtsu.edu/ itconf/proceed0 I/2I.pdf. (Accessed 20 September 2008).

Ebrary. 2007. Global faculty e-book survey. [Online]. http://www.ebrary.com/corp/collateral/en/Survey/ebrary_faculty_ survey_2007.pdf. (Accessed 27 January 2008).

Ebrary. 2008a. Global student e-book survey. [Online]. http://www.ebrary.com/corp/collateral/en/Survey/ebrary_ student survey 2008.pdf. (Accessed I 3 April 2008).

Ebrary. 2008b. 2008 Global student e-book survey - cloned for librarians. [Online]. http://www.ebrary.com/corp/collateral/en/Survey/ ebrary_student_survey_cloned_2008.pdf. (Accessed 10 September 2008).

Engel, D. \& Robbins, S. 2008. Evvolving roles for electronic resources librarians. In: H. Yu \& S. Breivold, eds. Handbook on library electronic resources management. Hershey: Idea Group. I05-I 20.

Hardesty, S. \& Sugarman, T. 2007. Academic librarians, professional literature, and new technologies: a survey. The Journal of Academic Librarianship, 33:196-205.

Heath, M., Jubb, M. \& Robey, D.H. 2008. E-publication and open access in the arts and humanities in the UK. Ariadne, (54). [Online]. http://www.ariadne.ac.uk/issue54/heath-et-al/. (Accessed 25 September 2009).

JISC. See Joint Information Systems Committee.

Joint Information Systems Committee (IISC). 2008. JISC national e-books observatory project. [Online]. http:// www.jiscebooksproject.org/. (Accessed 27 January 2009).

Korat, O. \& Shamir, A. 2007. Electronic books versus adult readers: effects on children's emergent literacy as a function of social class. Journal of Computer Assisted Learning, 23 (3):248-259.

Lenzini, R.T. 2002. The graying of the library profession: a survey of our professional association and their responses. Searcher, 10 (7):88-97.

Levine-Clark, M. 2006. Electronic book usage: a survey at the University of Denver. Portal: Libraries and the Academy, 6(3): 285299.

McKiel, A. 2007. Ebrary.com. 2007. [Online]. http://www.ebrary.com/corp/collateral/en/Survey/ebrary_eBook_survey_2007. pdf. (Accessed I4 June, 2008).

Newman, M. \& Bui, A. 2010. HighWire press-librarian ebook survey and analysis. [Online]. http://highwire.stanford.edu/PR/ HighWireEBookSurvey2010.pdf. (Accessed 23 April 2010).

Oduwole, A.A .2000. A study of the use of CD-ROM databases in Nigerian academic libraries, Journal of Information Science, 26 (5):364-9.

Pavlik, J.V. 2008. Media in the digital age. New York: Columbia University Press.

Piper P.S. \& Collamer B.E. 200I.Male librarians: men in a feminised profession. Journal of Academic Librarianship, 27(5):406-4I I.

Renner, R.A. 2007. eBooks-costs and benefits to academic and research libraries. [Online]. http://www.springer.com/cda/content/ document/cda_downloaddocument/eBook + White + Paper.pdf?SGWID=0-0-45-4 I5 198-0. (Accessed 28 June 2009).

Rogers, M. 2006. Ebooks struggling to find a niche. Library Journal, I 3 I (I I ):25-26.

Rowlands, I., Nicholas, D., Jamali, H.R. \& Huntington, P. 2007. What do faculty and students really think about e-books? Aslib Proceedings, 59(6):489-5II.

Rowlands, I., Nicholas, D., Williams, P., Huntington, P., Fieldhouse, M., Gunter, B., Whitey, R., Jamali, H.R., Dobrowolski, T. \& Tenopir, C. 2008. The Google generation: the information behaviour of the researcher of the future. Aslib Proceedings, 60 (4):290-310.

Silberer, Z. \& Bass, D. 2007. Battle for ebook mindshare:it's all about the rights. IFLA Journal, 33(I):23-3I. 
Silipigni-Connaway, L. \& Wicht, H. L. 2007. What happend to the e-book revolution?: the gradual intergration of e-books into academic libraries. Journal of Electronic Publishing, 10 (3) [Online]. http://hdl.handle.net/2027/spo.333645I.0010.302. (Accessed 16 December 2008).

Siracusa, J. 2009. The once and future e-book: on reading in the digital age. Ars Technica. [Online]. http://arstechnica.com/features/ 2009/02/the-once-andfuture-e-book.ars. (Accessed 3 February 2009).

Sprague, N. \& Hunter, B. 2008. Assessing e-books: taking a closer look at e-book statistics. Library Collections, Acquisitions, and Technical Services, 32 (3-4): I50-I57.

Springer. 2009. White paper. EBooks: the end user perspective. [Online]. http://www.springer.com/cda/content/document/ cda_downloaddocument/. (Accessed 2 March 2009).

Stover, M. 2000. Reference librarians and the internet: a qualitative study. Reference Service Review, 28(I):39-49.

Veldsman, S. 2008. eBooks: new pricing models and access. elFL.net (electronic information for libraries general assembly 2008 program. [Online]. http://www.eifl.net/cps/sections/services/knowledge/ga_all/ga2008/ga2008-programe-docs-pub. (Accessed I4 May 2009).

Wathen, C.N. \& Burkekk, J. 2002. Believe it or not: factors influencing credibility on the web. Journal of the American Society for Information Science and Technology, 53(2): I34-44.

Wikipedia Contributors. 2009. Edition (book). Wikipedia: the Free Encyclopedia. [Online]. http://en.wikipedia.org/wiki/Edition_ (book). (Accessed 23 August 2009).

Woll, T. \& Nathan, J. 2006. Publishing for profit. 3rd ed. Chicago: Chicago Review Press.

Woodward, H. \& Edward, L. 200 la. Shaping a strategy for e-book: an issues paper. [Online]. http://www.jisc-collections.ac.uk/ workinggroups/ebooks/wg_ebooks_strategyl.aspx. (Accessed 20 June 2009).

Woodward, H. \& Edward, L. 200 Ib. Shaping a strategy for e-book: the role of the DNER. VINE, 3I (4):5-I I. 